Shamayim: Jurnal Teologi dan Pendidikan Kristiani

Volume 1, Nomor 1, 2020 (58-77)

http://hologos.college/ejournal/index.php/shamayim/index

\title{
Implementasi Kepemimpinan Yesus Kristus Menurut Yohanes 13:1-20
}

\author{
Hotman P. Simanjuntak \\ Sekolah Tinggi Teologi Arastamar Riau \\ hotmanp.simanjuntak76@gmail.com
}

\begin{abstract}
Leadership is an integral part of all human civilization because everyone needs a leader. Leader and leadership cannot be separated from one another. Where the purpose of choosing a leader is to influence, admonish, direct the people they lead to the goals they want to achieve. Thus, leadership is more likely to function and not position. The world offers and shapes leaders who are more focused on position and authority. This clearly contradicts the leadership of Jesus Christ in John 13: 1-20. It happens in Christian leadership today. Some of the Christian leaders have not been able to be examples of holiness in life, where they are not willing and able to leave old habits. Sometimes some of the Christian leaders live in enmity, either with the congregation, council or with fellow Christian leaders. Based on the above problems, the author will examine more deeply referring to the title: "Implementation of the Leadership of Jesus Christ According to John 13: 1-20, with the aim and purpose of knowing the relevance of the leadership model of Jesus Christ According to John 13: 1-20 for Christian leadership in the future. now, in order to become a guide in Christian leadership today.
\end{abstract}

Key words: Implementation, Leadership, Jesus Christ, John 13:1-20

\begin{abstract}
Abstrak
Kepemimpinan adalah bagian yang integral dalam sepanjang peradaban manusia karena semua orang membutuhkan pemimpin. Pemimpin dan kepemimpinan tidak dapat dipisahkan satu dengan yang lainnya. Dimana tujuan dipilihnya seorang pemimpin adalah untuk mempengaruhi, menegur, mengarahkan supaya orang-orang yang dipimpinnya sampai kepada tujuan yang ingin dicapai. Dengan demikian kepemimpinan lebih cenderung kepada fungsi dan bukan posisi. Dunia menawarkan dan membentuk para pemimpin yang lebih berfokus kepada posisi dan otoritas. Hal ini jelas bertentangan dengan kepemimpinan Yesus Kristus dalam Yohanes 13:1-20. Hal itu terjadi dalam kepemimpinan Kristen pada masa kini. Sebagian dari pemimpin Kristen belum mampu untuk menjadi teladan dalam kekudusan hidup, dimana mereka belum mau dan mampu untuk meninggalkan kebiasaan lama. Terkadang sebagian dari pemimpin Kristen hidup dalam perseteruan, baik dengan jemaat, majelis maupun dengan sesama pemimpin Kristen.
\end{abstract}


Berdasarkan permasalahan di atas, maka penulis akan meneliti lebih dalam merujuk pada judul: "Implementasi Kepemimpinan Yesus Kristus Menurut Yohanes 13:1-20, dengan maksud dan tujuan untuk mengetahui relevansi model kepemimpinan Yesus Kristus Menurut Yohanes 13:1-20 bagi kepemimpinan Kristen masa kini, supaya dapat menjadi pedoman dalam kepemimpinan Kristen masa kini.

Kata kunci: Implementasi, Kepemimpinan, Yesus Kristus, Yohanes 13:1-20.

\section{Pendahuluan}

Kepemimpinan adalah bagian integral di sepanjang peradaban manusia karena semua orang membutuhkan pemimpin dan semua orang bisa menjadi seorang pemimpin. Pemimpin dan kpemimpinan tidak dapat dipisahkan satu dengan yang lainnya. Octavianus menjelaskan bahwa pemimpin Kristen berarti individu atau pribadi yang dipanggil oleh Tuhan untuk melaksanakan tugas kepemimpinan. ${ }^{1}$ Tugas kepemimpinan Kristen dilandasi oleh faktor teori kepemimpinan, seperti yang diungkapkan Northouse bahwa: "Setidaknya ada tiga teori dasar tentang pemimpin, teori genetis, teori sosial, dan teori ekologis. Teori genetis bahwa seorang menjadi pemimpin karena ia dilahirkan bahkan sejak dalam kandungan ia telah ditetapkan sebagai pemimpin, karena itu ia dianggap mewarisi dari orangtua mereka potensi atau kemampuan bawaan sebagai pemimpin atau pemimpin alamiah. Teori sosial bahwa sekalipun seseorang tidak lahir dari keturuanan pemimpin, namun apabila ia memiliki keinginan yang kuat disertai dengan belajar dan kerja keras, maka ia bisa menjadi pemimpin yang efektif. Dalam hal ini, pemimpin yang demikian adalah pemimpin yang diciptakan melalui pendidikan, pelatihan dan pengalaman. Inilah yang disebut sebagai teori pembentukan. Teori sosial bahwa pengalaman memimpin yang harus dijadikan sebagai pengalaman memimpin menuju ke arah kedewasaan memimpin. Teori ekologis adalah gabungan dari teori genetis dan teori sosial." ${ }^{2}$ Dengan demikian setiap orang yang akan menjadi pemimpin sudah memahami dan mulai menerapkan teoriteori di atas sehingga banyak pemimpin dapat menjalankan kepemimpinannya dalam memimpin. Kepemimpinan Kristen adalah kepemimpinan yang Alkitabiah. Berbicara tentang kepemimpinan yang Alkitabiah sudah pasti harus melihat bagaimana Allah dan beberapa tokoh dalam Alkitab memimpin.

Kepemimpinan Allah, semua hal yang baik yang pernah kita lihat bahkan yang belum pernah kita bayangkan sekalipun, semua ada dalam diri Allah karena Dia adalah Allah dan sempurna artinya Allah tidak berubah, ialah tidak memiliki perubahan apa pun dalam diri-Nya, dalam kesempurnaan-Nya, maksud-maksud-Nya dan janji-janji-Nya. Allah abadi, ialah Allah berada di atas batas-batas waktu, tanpa awal dan tanpa akhir tanpa pergantian waktu. Allah Mahatahu, ialah kehadiran-Nya dimana-mana, tanpa batas ruang dan waktu. Allah Mahakuasa, ialah sesuatu yang berbeda dari kuasa manusia. Allah kudus, kekudusan dapat disebut sebagai sifat Allah yang paling khas, kemilau dari segala

\footnotetext{
${ }^{1}$ Petrus Octavianus, Alih Generasi Dan Kepemimpinan Dalam Garis Firman Allah, (Batu: Literatur YPPII, 2004), 4

${ }^{2}$ Peter G. Northouse, Kepemimpinan: Teori dan Praktik, (Jakarta: PT Indeks, 2013), 5
} 
keberadaan-Nya yang memisahkan diri-Nya dengan ciptaan-Nya karena Ia tak terhampiri dalam segala kesempurnaan-Nya. Kekudusan-Nya itulah semarak dan kemegahan intelektual dan moral-Nya, kemurnian etis yang olehnya Ia menyukai kebaikan dan membenci yang jahat. ${ }^{3}$

Bertolak dari sifat-sifat Allah maka kita dapat mengetahui bahwa kepemimpinan Allah adalah kasih dan adil. Hal ini nampak jelas ketika Allah memanggil Musa untuk membebaskan bangsa Israel dari perbudakan dan Allah menghukum bahkan membunuh mereka yang tidak taat dengan menyembah patung anak lembu emas (Kel. 2: 23-4:17; Kel. 32). Puncak kasih dan keadilan Allah ialah penggenapan Mesias. Berkaitan dengan itu Piper menuliskan bahwa Allah Bapalah yang menyerahkan Kristus untuk mati. Allah menyerahkan Kristus untuk jalan pendamaian oleh darah-Nya. Inilah arti jalan pendamaian: Allah mengalihkan murka-Nya sendiri melalui kematian Anak-Nya. ${ }^{4}$ Dalam keadilan dan kasih Allah semua sifat Allah nampak jelas dan hanya sebatas yang dinyatakan-Nya.

Karena itu, menjadi seorang pemimpin bukanlah sebuah tanggung jawab yang mudah untuk dilakukan, memimpin bukanlah semudah membalikkan telapak tangan karena kepemimpinan bukan sekedar bicara tentang posisi tetapi lebih kepada fungsi. Demi mencapai tujuan itu, seorang pemimpin harus memiliki kepedulian terhadap orang lain people oriented, yaitu sejauh mana pemimpin memperhatikan kebutuhan anggota tim, kepentingan dan bidang pribadi ketika memutuskan cara terbaik untuk menyelesaikan tugas. ${ }^{5}$ Menurut Sendjaya: Kepemimpianan yang sehat dan efektif adalah kepemimpinan yang Biblikal. ${ }^{6}$ Jika demikian para pemimpin harus melihat kembali bagaimana Yesus Kristus memimpin. Dalam Yohanes 13: 4-5 tertulis: "Sementara hari Paskah tiba dan Yesus bersama-sama dengan mereka, lalu bangunlah Yesus dan menanggalkan jubah-Nya. Ia mengambil sehelai kain lenan dan mengikatkannya pada pinggang-Nya. Kemudian Ia menuangkan air ke dalam sebuah basi, dan mulai membasuh kaki murid-murid-Nya lalu menyekanya dengan kain yang terikat pada pinggang-Nya."

Dewasa ini banyak lembaga, Institusi, gereja bahkan kelompok kecil sekalipun mengalami persoalan yang sama dan begitu krusial, yaitu krisis kepemimpinan, karena seharusnya pemimpin adalah patron bagi sekelompok orang yang dipimpinnya. Lemahnya kepemimpinan seseorang maka akan memberikan dampak yang buruk bagi pertumbuhan dan kemajuan dari lembaga, institusi maupun gereja dimana ia memimpin. Maka dari itu, harus waspada dan selektif untuk memilah dan memilih pemimpin yang bekualitas. Hal ini dikarenakan gereja pun tidak imun dari krisis kepemimpinan. Gereja yang seharusnya menghasilkan pemimpin yang tinggi iman, tinggi ilmu dan tinggi pengabdian malah

\footnotetext{
${ }^{3}$ J.D. Douglas, Ensiklopedi Alkitab Masa Kini Jilid 1,(Jakarta: Yayasan Komunikasi Bina Kasih, 1992), 34

${ }^{4}$ John Piper, Kesukaan Allah, (Surabaya: Momentum, 2008), 187

${ }^{5}$ https://www/google.com/amp/s/mebiso.com.cari-tahu-tipe-kepemimpinan-anda-berdasarkan-leadershipgrid-amp. 13 Juli 2007

${ }^{6}$ Sendjaya, Kepemimpinan Kristen, (Yogyakarta: Kairos Books, 2004), 11
} 
terkontaminasi dengan berbagai masalah kepemimpinan. ${ }^{7}$ Bekenaan dengan hal ini, Alkitab telah mencatat permasalahan tentang krisis kepemimpinan hamba ada dalam kehidupan para murid Yesus seperti yang tertulis dalam Lukas 22:24: “Terjadilah juga pertengkaran di antara para murid Yesus, siapakah yang dapat dianggap terbesar di antara mereka." Banyak hal kontradiktif antara kepemimpinan manusia dengan kepemimpinan Tuhan, atau kepemimpinan yang menjadikan seorang sebagai orang besar dan kepemimpinan hamba. Tuhan Yesus adalah teladan seorang pemimpin yang datang sebagai hamba untuk mati di kayu salib bagi orang-orang yang dipimpin-Nya (Band Fil. 2:8-11). Hal yang berbeda nampak dalam kepemimpinan manusia yang hanya mencari keuntungan bagi dirinya sendiri. Pusat kemauan atau keinginan dalam dirinya, serta suara hati yang seharusnya peka terhadap kebenaran telah menjadi tumpul dipengaruhi arogansi dan keserakahan dunia (Rom. 7:22). Teladan Yesus "Melayani dan bukan dilayani" tidak lagi menempati tempat utama. Kepemimpinan seperti ini memberi pengaruh pada pertumbuhan rohani orang yang dipimpinnya, baik secara kualitas maupun kuantitas. Sebagai contoh, ada beberapa pemimpin gereja yang rela menanggalkan jubah kependetaannya dan lebih memilih untuk memulai usaha atau kerja yang lain sebab ia merasa bahwa beban dan pergumulan yang dihadapinya dan keluarganya sudah demikian berat. ${ }^{8}$ Oleh sebab itu tidak ada seorang pun yang mampu mejalankan kepemimpinan yang baik tanpa berkaca kepada model kepemimpinan Yesus Kristus dan meneladani bagaimana cara Yesus Kristus memimpin. Relasi yang baik dengan Tuhan adalah faktor utama yang harus ada di dalamnya.

Pemimpin disebut leader, akar katanya to lead. Dalam kata itu terkandung beberapa arti yang saling erat berhubungan: bergerak lebih awal, berjalan di depan, mengambil langkah pertama, memelopori, mengarahkan pikiran pendapat tindakan orang lain, membimbing, menuntun, menggerakkan orang lain melalui pengaruhnya. ${ }^{9}$ Suekarno menuliskan:

"Pemimpin harus bersikap sebagai pengasuh yang mendorong, menuntun dan membimbing asuhannya. Beberapa asas dalam Pancasila itu meliputi Ing Ngarsa Sung Tuladha: pemimpin harus mampu dengan sifat dan perbuatannya menjadikan dirinya pola anutan dan ikutan bagi orang-orang yang dipimpinnya. Ing Madya Mangun Karsa: pemimpin harus mampu membangkitkan semangat berswakarsa dan berkreasi pada orang-orang yang dibimbingnya. Tut Wuri Handayani: pemimpin harus mampu mendorong orang-orang yang disuruhnya berani berjalan di depan dan sanggup bertanggung jawab."10

Dengan demikian penulis menyimpulkan pemimpin adalah seorang yang berkharisma, dan berkarakter yang diyakini mampu untuk memimpin, mendorong,

\footnotetext{
${ }^{7}$ Ibid., 17

${ }^{8} \mathrm{Https}$ //www.googe.co.id/amp/s/blessedday4us.wordprees.com/2010/06/18/kehidupan-danpergumulan-seorang-hamba-tuhan/amp/ 27 nov 10.08

${ }^{9}$ A.M. Mangunhardjana, Kepemimpinan, (Yogyakarta: KANISIUS, 1986), 11

${ }^{10}$ Plenoinfo.blogspot.com/2016/08/pengertian-kepemimpinan-secara.html?=\#
} 
membimbing, menggerakkan orang melalui pengaruhnya. ${ }^{11}$ Kepemimpinan adalah pengaruh, yaitu kemampuan seseorang untuk mempengaruhi orang lain. Orang hanya dapat memimpin orang lain sejauh ia dapat memengaruhi mereka. Untuk itu kepemimpinan merupakan proses timbal balik antara mereka yang ingin memimpin dengan mereka yang memilih untuk mengikuti. ${ }^{12}$ Blanchard dan Hodges, berpendapat:

\begin{abstract}
"Kepemimpinan adalah suatu proses mempengaruhi setiap kali Anda berusaha mempengaruhi cara berpikir, prilaku, atau perkembangan orang menuju pencapaian suatu tujuan dalam kehidupan pribadi atau profesional mereka, Anda sedang menjalankan peran sebagai pemimpin. Kepemimpinan adalah suatu tindakan yang sama intinya seperti kata-kata bimbingan dan dorongan kepada seseorang yang dicintai. Kepemimpinan juga menyangkut pendistribusian sumber daya dalam suatu organisasi untuk mencapai atau menyelesaikan suatu tujuan tertentu."13
\end{abstract}

Oleh sebab itu kepemimpinan menjadi sangat penting dimana kepemimpinan adalah cara mengartikulasikan visi, mewujudkan nilai dan menciptakan lingkungan guna mencapai sesuatu. Kepemimpinan umum dan kepemimpinan Alkitab atau kepemimpinan Kristen adalah berbeda. Hal paling mendasar yang membedakan kepemimpinan Kristen dan kepemimpinan umum adalah motivasi. Kepemimpinan Kristen adalah kepemimpinan yang dimotivasi oleh kasih, ditujukan untuk pelayanan yang dikenali oleh Kristus dan keteladanan-Nya. Pemimpin-pemimpin Kristen yang terbaik mencerminkan sepenuhnya sifat penggabdian yang tanpa pamrih (tidak mementingkan diri sendiri), teguh hati, tegas, dan berbelaskasihan. ${ }^{14}$ Yang membedakan seorang pemimpin Kristen dengan pemimpin lainnya adalah kualitas kepemimpinannya. Kualitas kepemimpinan pada gilirannya, sangat ditentukan oleh motivasi. Hanya motivasi yang baik yang bisa melahirkan pemimpin yang baik, seperti cuma benih yang baik yang dapat menghasilkan tanaman yang baik. ${ }^{15}$ Lumintang berpendapat:

"Kepemimpinan adalah suatu aktivitas sadar seseorang yang karena panggilan Tuhan bagi dirinya sendiri sebagai alat Tuhan untuk mendeklarasikan Tuhan sebagai pemimpin yang melayani semua umat manusia pada umumnya dan melayani umat percaya (gereja) pada khususnya dengan cara memberitakan firman-Nya yang murni baik perkataan maupun perbuatan, menjadi model yang hidup, rela memberi segalanya untuk umat yang dipimpin dan memberi petunjuk untuk melihat kedepan (visi), memutuskan, mempengaruhi memperlengkapi, menuntun, memotivasi, mengevaluasi umat, Tuhan dalam terang Firman Tuhan demi terlaksananya kehendak Tuhan secara berkesinambungan dan terwujudnya

\footnotetext{
${ }^{11}$ J. Osland Sanders, Kepemimpinan Rohani, (Bandung: Klam Hidup, 1979), 20

${ }^{12}$ Kouzes Posner, Tantangan Kepemimpinan: edisi ketiga, (JAKARTA: Penerbit Erlangga, 2004), 25

${ }^{13}$ Klen Blanchard and Phil Hodges, Lead Like Jesus, (Tanggerang: Visimedia, 2007), 5

${ }^{14}$ Sudomo, Ciri Kepemimpinan Sejati, (Yogyakarta: Andi, 2009), 56

${ }^{15}$ Eka Darmaputra, Kepemimpinan Dalam Perspektif Alkitab, (Yogyakarta: Kairos Books, 2005), 27,29
} 
misi Tuhan dari generasi ke generasi di dalam dan melalui gereja kepada dunia di segala bidang." 16

Tentu hal ini tidak dapat dipisahkan dari model kepemimpinan Yesus yang menjadi teladan bagi kepemimpinan Kristen yaitu kepemimpinan didasarkan oleh kasih Allah. Hal ini terlihat lebih eksplisit dalam pemaparan paradigma kepemimpinan dalam Perjanjian Lama dan Perjanjian Baru, seperti yang dijelaskan berikut ini. Ada beberapa istilah yang dipakai untuk pemimpin di dalam Perjanjian Lama. Istilah yang dipakai untuk kata "pemimpin" adalah שֵ \{sar\} artinya pangeran, pemimpin,kepala, kepala suku, resmi, kapten. (Kel. 2:14). kata עָלָ (alah) artinya membawa, naik, mendaki (Kel. 32:1). ${ }^{17}$ Kedua kata adalah kata yang dipakai untuk Musa. Secara absolut kedudukan Pemimpin ini mutlak apabila diangkat oleh Tuhan dan terikat terhadap peraturan yang Tuhan tetapkan. Oleh sebab itu, umat Israel tidak boleh menyumpahi pemimpin atau pemuka tersebut di tengah-tengah mereka. Para pemimpin tersebut adalah milik Tuhan dan milik rakyat, suku dan Negara.

Pemimpin dalam Perjanjian Baru digunakan istilah $\dot{\eta} \gamma \epsilon \mu \omega \nu^{18}$ (hegemon) artinya seorang pemimpin, pemandu, penunjukan jalan, pengukur, sempurna, presiden, kepala, komandan, berdaulat. Newmar dalam bukunya mengartikan $\dot{\eta} \gamma \epsilon \mu \omega$ (hegemon) sebagai yang memerintah, penguasa, wali negri. ${ }^{19}$ Kata pemimpin ini nampak jelas dalam ungkapan, dan engkau Betlehem, tanah Yehuda, engkau sekali-kali bukanlah yang terkecil di antara mereka yang memerintah Yehuda, karena dari padamulah akan bangkit seorang pemimpin, yang akan menggembalakan umat-Ku Israel (Mat. 2:6). Pemimpin yang dimaksudkan di sini adalah pribadi Yesus yaitu Sang Mesias yang sudah dinubuatkan dalam kitab-kitab Perjanjian Lama. Yesus datang sebagai pemimpin yang memimpin, memandu, menunjukkan jalan kepada bangsa pilihan secara Rohani, yang sangat berbeda dengan konsep orang-orang Israel dimana mereka mengganggap dan mengharapkan seorang pemimpin secara politis. Scott menuliskan bahwa, bagi rakyat Yahudi pada umumnya, Sang Mesias tetap dipandang sama seperti Dia dipandang oleh Yesaya dan rekan-rekan sezamannya, yaitu sebagai Anak Daud yang akan membawa kemenangan dan kemakmuran kepada bangsa Yahudi bedasarkan keterangan dalam keempat Injil itu, tak mungkin diragukan lagi bahwa pemikiran popular rakyat banyak tentang Mesias pada umumnya bersifat Nasional dan politis. ${ }^{20}$ Jewish Encyclopedia menyatakan bahwa orangorang Yahudi "merindukan pembebas yang dijanjikan akan datang dari keturunan Daud, yang akan membebaskan mereka dari kuk perampas-perampas asing yang dibenci itu, mengakhiri pemerintahan Romawi yang kafir itu, dan menggantikannya dengan

${ }^{16}$ Stevri Indra Lumintang, Theologia Kepemimpinan Kristen, (Jakarta: Geneva Insani Indonesia, 2015), 9-10

${ }^{17}$ BibleWorks 7, LCC, c-/Program Files/ BibleWorks 7/inti/bw700.swc

${ }^{18}$ Ibid.

${ }^{19}$ Barclay M. Newman JR, Kamus Yunani-Indonesia Untuk Perjanjian Baru, (Jakarta: BPK Gunung Mulia, 2012), 74

${ }^{20}$ Ernest Findlay Scott, Kingdom And The Messiah, (Edinburgh: T. \& T. Clark, 1911), 23 
mendirikan pemerintahan-Nya sendiri yang penuh dengan damai dan keadilan. ${ }^{21}$ Gatenhaus merefleksikan keyakinan Yahudi yang umumnya berlaku pada masa Kristus: "orang-orang Yahudi menantikan Mesias sebagai seorang yang akan membebaskan mereka dari penindasan Romawi, pengharapan Mesianis pada dasarnya adalah demi kebebasan nasional."22 MacDowel menegaskan bahwa:

"Kehidupan dan pengajaran Yesus amat bertentangan dengan spekulasi Mesianis kaum Yahudi pada masa itu. Sejak masa kecilnya setiap orang Yahudi diajarkan bahwa bila Sang Mesias itu datang, maka ia akan menjadi pemimpin politik yang akan memerintah dan mengalahkan segala musuh-Nya. Dia akan membebaskan orang-orang Yahudi dari penjajahan pemerintah Romawi dan menggembalikan bangsa dan Negara Israel kepada tempatnya yang tepat." 23

Kedatangan Kristus sangat dinantikan oleh orang Yahudi karena Dia adalah Mesias, yang mampu membebaskan mereka dari kuk perhambaan Romawi dan yang akan menggembalikan keadaan Yahudi dari sisi politik. Klausner menambahkan bahwa, Mesias itu kian lama bukan saja menjadi penguasa politis yang menonjol, melainkan juga orang laki-laki yang memiliki kualitas-kualitas moral yang menonjol. ${ }^{24}$ Sehingga Dia yang mampu menjadi pahlawan mereka. Namun itulah faktanya bahwa Yesus datang ke dunia dan menjadi manusia bukan untuk menjadi pembebas atau penyelamat secara politis melainkan pembebas atau penyelamat secara rohani. Dialah yang telah ditinggikan oleh Allah sendiri dengan tangan kanan-Nya menjadi pemimpin dan Juruselamat supaya Israel dapat bertobat dan menerima pengampunan dosa (Kis. 5:31).

Yesus adalah Anak Allah (Mesias) yang dikandung dan dilahirkan oleh seorang perawan dalam sebuah keluarga yang sederhana. Ayahnya bernama Yusuf dan ibunya adalah Maria. Ismail menjelaskan bahwa "orang Yahudi mempunyai gambaran atau harapan yang sangat tinggi tentang Yesus, yaitu bahwa Yesus adalah orang Istimewa dan berkedudukan tinggi. Ternyata Ia tidak datang sebagai orang besar dan berkuasa, justra Ia muncul sebagai orang kecil dan sederhana. Yesus mempunyai kedudukan istimewa (karena Dia Allah) namun Ia tidak minta diperlakukan istimewa (lahir di kandang domba)." 25 Yesus lahir di Betlehem pada masa pemerintahan Raja Herodes. Pada usia delapan hari Ia disunat, usia dua belas tahun Ia sudah bercakap-cakap dengan imam-imam di Bait Allah, Usia tiga puluh dibaptis dan usia tiga puluh tiga tahun Ia meninggal. Ia hidup selama tiga puluh tiga tahun, melayani selama tiga tahun bersama kedua belas murid-Nya dan dampaknya sampai sekarang. Menebus dosa manusia melalui kematian-Nya di kayu salib. Yesus adalah pemimpin yang sejati.

$21 \ldots$, He Jewish Encyclopedia Jilid 8, (New York: Funk \& Wagnalls, 1906), 508

22 Jacob Gartenhaus, The Jewis Conception of The Messiah, (Christianity Today, 1970), 8-10

${ }^{23}$ Josh MacDowell, Benarkah Yesus Itu Allah, (Jakarta: BPK Gunung Mulia, 1997), 63

${ }^{24}$ Joseph Kalusner, The messianic Idea In Israel, (New York: MacMillan, 1995), 23

${ }^{25}$ Andar Ismail, Selamat Melayani Tuhan, (Jakarta: BPK Gunung Mulia, 2009), 53 
Setiap pemimpin yang baik memiliki tujuan dalam kepemimpinannya. Berikut dua tujuan pemimpin menurut Rush, pertama sebab ia memimpin. tujuan yang pertama ini adalah yang memotivasi pemimpin untuk berinisiatif dalam menjadi teladan bagi orang lain. Sekali ia memiliki pengikut yang memiliki tujuan yang sama dengannya, pemimpin yang baik akan mengembangkan tujuan yang kedua adalah melatih pengikutnya untuk menjadi pemimpin yang efektif sehingga tujuan yang pertama dapat tercapai dengan lebih cepat dan efektif. ${ }^{26}$ Enns dalam bukunya menyoroti kepemimpinan Yesus bahwa:

\begin{abstract}
"Yesus Kristus membawa perubahan yang sangat besar dalam kehidupan bangsa Israel terutama dalam pemahaman ukum Taurat dan pola ibadah bangsa Israel. Tuhan Yesus adalah seorang pemimpin yang luar biasa, Dia mengkritik dan membawa sebuah perubahan dalam sikap dan pola hidup bangsa Yahudi. Yang dalam kehidupan mereka terlalu menekankan aturan-aturan hukum Taurat, tetapi tidak melakukannya dalam hidup mereka secara benar. Kehidupan dan pelayanan Tuhan Yesus sangat jelas digambarkan oleh penulis kitab Injil Matius, Markus dan Lukas. Para penulis Injil Sinoptik adalah tangan pertama dan menjadi saksi mata dari kehidupan dan pelayanan Tuhan Yesus."27
\end{abstract}

Oleh sebab itu kepemimpinan Yesus Kristus tidak bisa dipisahkan dari kehidupan dan pelayanan-Nya. Hal ini tentu tidak lepas dari konteks kebudayaan sekitar. Konteks kebudayaan dari sejumlah metafora agraris tentang gaya kepemimpinan Yesus dimaksudkan untuk memengaruhi dan mengajari setiap pemimpin. semua itu dimaksudkan untuk memberikan cara memimpin dalam kepemimpinan. ${ }^{28}$ Adapun cara Yesus memimpin adalah sebagai berikut; Pertama, melayani sebagai seorang hamba. Yesus datang untuk melaksanakan misi-Nya menyelamatkan umat manusia dari dosa. Ia datang dengan kerendahan hati-Nya untuk memberikan teladan yang harus dipanuti oleh muridNya dan semua manusia yang percaya kepada-Nya. Kedua, Menjadi teladan. Ialah menjadi penutan, atau menjadi contoh. Dalam Alkitab kita dapat melihat beberapa teladan yang Yesus berikan dalam kepemimpinan-Nya yaitu, teladan dalam berdoa, teladan dalam kasih, teladan dalam pelayanan. Ketiga, Sebagai gembala. Mazmur 23 yang berbunyi "Tuhan adalah gembalaku takkan kekurangan aku". Mazmur ini memiliki makna yang mendalam dimana Daud merefleksikan kehidupannya bersama dengan Tuhan yang adalah gembalanya. Gembala mengenal domba-dombanya, gembala menjaga dan melindungi, gembala menuntun dan membimbing serta memperhatikannya dan memelihara kawanan dombanya. Menurut Wofford:

"Sebagai gembala yang baik, Yesus memperhatikan umat-Nya yang hidup di zaman-Nya dan Ia menyiapkan gereja masa depan. Ia menyingkirkan segala kelemahan manusia (Mat. 8:16-17), mengusir roh jahat (Mrk. 6:7),

\footnotetext{
${ }^{26}$ Myron Rush, The New Leader a Revolutionary Approach to Effective Leadership, (Wheaton: Victor Books, 1987), 57-58

${ }^{27}$ Paul Enns, The Moody Handbook of Theology, (Malang: Literatur SAAT, 2004), 96

${ }^{28}$ Gary Goodlell, Cara Yesus Memimpin, (Yogyakarta: ANDI, 2012), 33
} 
mengkhotbahkan tentang pertobatan (Mrk. 6:12), dan memberitakan kabar baik tentang kerajaan Allah yang sudah dekat (Mrk. 1:15). Ia memberdayakan muridmurid-Nya untuk mengikuti jejak-Nya (Luk. 9:1; 10: 1-24) dan menugaskan mereka untuk pemimpin dan menggembalakan gereja-Nya (Mrk. 16: 15; Yoh. 21: 15-19). Sekalipun fokus utamanya adalah kebutuhan rohani manusia, namun Ia tidak mengabaikan kebutuhan fisik manusia yang sering kali menyiksa."29

Model Yesus sebagai pemimpin adalah teladan dari sebuah kepemimpinan yang sejati. Kepemimpinan kristen adalah kepemimpinan yang meneladani kepemimpinan Yesus.Yesus adalah pribadi yang begitu menarik karena Dia adalah tokoh kepemimpinan yang sejati. Dia tidak hanya memiliki karisma namun juga memiliki karakter yang begitu spesial, untuk itu setiap orang tidak akan mengerti apalagi menikmati kepemimpinan Tuhan Yesus tanpa memahami dasar dari kepemimpinan-Nya terlebih dahulu. Kata

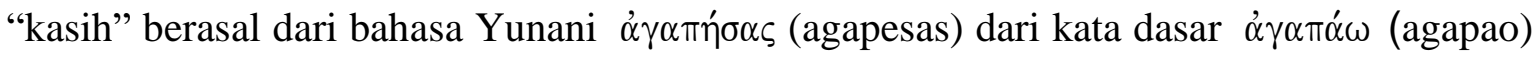
yang memiliki arti mengasihi, menunjukkan kasih, menyukai. ${ }^{30}$

Kata $\alpha \gamma \alpha \pi \eta ́ \sigma \alpha \varsigma$ (agapesas) dalam NIV dan KJV menggunakan kata having loved yang artinya mengasihi dan kasih itu menjadi kepemilikan dalam dirinya yang sudah dilakukan. Kata ঝ̇ $\gamma \alpha \pi \eta ́ \sigma \alpha \varsigma$ (agpesas) merupakan kata kerja aorist active participle masculine singular nominative. ${ }^{31}$ Aorist adalah tense untuk menyatakan bahwa sesuatu hal pernah terjadi atau pernah dilakukan namun berdampak. ${ }^{32}$ Active artinya terus menerus. Participle adalah kata kerja yang menjadi kata sifat (menjadi kebiasaan). ${ }^{33}$ Masculine singular menyatakan orang (laki-laki) tunggal. Nominative adalah bentuk subyek. ${ }^{34}$ Oleh sebab itu kata kerja aorist active participle masculine singular nominative dapat diartikan perbuatan yang telah dilakukan tetapi subyek itu yang aktif melakukannya. Sehingga dapat disimpulkan bahwa Yesus telah satu kali mengasihi murid-murid-Nya dan Yesus terus mengasihi mereka karena kasih adalah sifat Yesus. Hendriksen menjelaskan bahwa Dia (Yesus) memiliki kasih yang terus ada untuk murid -Nya sampai waktu dimana Yesus menunjukkan kasih-Nya yang seutuhnya. ${ }^{35}$ Gaebelein menambahkan salib menjadi pembuka dari zaman baru bagi orang percaya. Yohanes menghubungkan ini dengan manifestasi dari Kasih Yesus bagi murid-Nya. Itu berarti bahwa Yesus meneruskan kasihNya kepada murid-Nya hanya sampai batas akhir karir pelayanan-Nya tetapi kasih-Nya itu tidak ada batas. ${ }^{36}$ Kasih yang seutuhnya itu adalah kematian Yesus di kayu salib untuk menebus dosa manusia (termasuk para murid-Nya). Maka dari itu Yesus menyelesaikan

\footnotetext{
${ }^{29}$ Jerry C. Wofford, Kepemimpinan Kristen Yang Mengubahkan, (Yogyakarta: ANDI, 2001), 21

${ }^{30}$ Hasan Sutanto, Perjanjian Baru Interlinier Yunani-Indonesia Jilid II, (Jakarta: LAI, 2014), 4

${ }^{31}$ Hasan Sutanto, Jilid I ..., 568

${ }^{32}$ J.W. Wenham, Bahasa Yunani Koine, (Malang: SAAT, 1987), 77

${ }^{33}$ William D. Mounce, Basics of biblical Greek, (Michigan: Zondervan Publishing House, 2015), 233

${ }^{34}$ Agus Sutanto, Tata Bahasa Yunani Koine, (Semarang: Bina Media Informasi, 2011), 28

${ }^{35}$ William Hendriksen, New Testament Commentary John, (USA: Billing and Sons Limited), 221

${ }^{36}$ Frank E. Gaebelein, The Expositir's Bible Commentary, (USA: New York International Bible Society), 135
} 
pelayanan-Nya dan itu merupakan bagian dari tindakan yang penuh semangat atau antusias dari dalam diri-Nya. ${ }^{37}$

Berdasarkan pemaparan di atas, maka penulis memiliki pemahaman bahwa dasar dari kepemimpinan dan pelayanan Yesus adalah kasih yang sempurna dan tanpa batas. Dengan demikian setiap pemimpin Kristen tidak akan pernah bisa menjadi pemimpin yang baik bila tidak mendasari pelayanannya dengan kasih Yesus yang sempurna dan tanpa batas. Setelah mengerti dengan benar apa yang menjadi dasar kepemimpinan Yesus Kristus, maka perlu juga untuk mengerti karakteristik kepemimpinan-Nya supaya setiap pemimpin dapat memperbaharui diri sehingga kedepannya menjadi pemimpin-pemimpin yang lebih baik. Adapun karakteristik kepemimpinan Tuhan Yesus yakni, visioner, rendah hati, melayani, teladan, sebagai hamba.

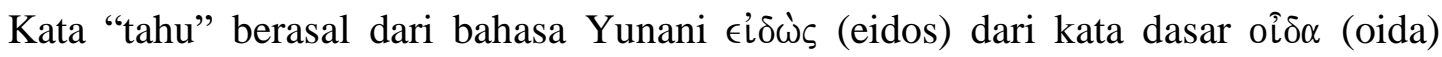
yang memiliki arti tahu, mengenal, tahu bagaimana, mengerti, dapat, ingat, menghormati, memperhatikan. ${ }^{38}$ NIV menggunakan kata Jesus knew artinya Yesus tahu sebelumnya, sedangkan KJV menggunakan kata "Jesus Knowing" artinya Yesus mengerti dengan sepenuhnya, memahami atau sungguh-sungguh paham. Kata $\epsilon \dot{\ell} \delta \dot{\omega} \varsigma$ (eidos) merupakan kata kerja perfect active participle masculine singular nominative. ${ }^{39}$ Perfect merupakan perbuatan yang sempurna sampai sekarang. Active artinya terus menerus. Participle adalah kata kerja yang menjadi kata sifat (menjadi kebiasaan). ${ }^{40}$ Masculine singular menyatakan orang (laki-laki) tunggal. Nominative adalah bentuk subyek. ${ }^{41}$ Oleh sebab itu kata kerja perfect active participle masculine singular nominative dapat diartikan bahwa pengetahuan Yesus itu sempurna sampai sekarang dan terus menerus Ia mengetahui waktunya. Pentecost berpendapat; Kepemimpinan Tuhan Yesus ditandai dengan pengetahuan-Nya bahwa "saatnya telah tiba." Sedangkan Pentecost menulis: Christ's knowledge of who He was, of the position to which He had been appointed, and of the destiny that awaited Him made Him confident in His action. ${ }^{42}$ Dengan demikian pengetahuan Kristus tentang siapakah Dia, dari posisi yang telah ditunjuk-Nya, dan tentang takdir yang menantikan Dia membuat Dia percaya diri dalam tindakan-Nya. ${ }^{43}$ Yesus sepenuhnya sadar mengenai kekuasaan-Nya, asal keilahian-Nya, dan kemana tempat akhir-Nya. "44 "Yohanes menekankan fakta bahwa Yesus hidup dalam kehendak Bapa. Wiersbe menyatakan:

"Tuhan Yesus dimuliakan melalui kematian, kebangkitan, dan kenaikan-Nya. Dari sudut pandang manusia, itu berarti penderitaan; Tapi dari sudut pandang

\footnotetext{
${ }^{37}$ Barnabas Lindars, The New Century Bible Commentary The Gospel of John, (USA: Division Of Christian Education, 1952), 448

${ }^{38}$ Hasan Sutanto, Interlinier Perjanjian Baru Jilid I..., 559

${ }^{39}$ Ibid.

${ }^{40}$ William D. Mounce, Basics of biblical Greek..., 223

${ }^{41}$ Agus Sutanto, Tata Bahasa Yunani Koine, (Semarang: Bina Media Informasi, 2011), 28

42 J. Dwight Pentecost, The Words and Works of Jesus Christ: A Study of The Life of Christ, (Grand Rapids, Michigan: Zondervan, 1981), 427

${ }^{43}$ J. Dwight Pentecost, The Words and Works of Jesus Chris ...,427

${ }^{44}$ Frank E. Gaebelein, The Expositir's Bible Commentary..., 136
} 
ilahi, itu berarti kemuliaan. Dia akan segera meninggalkan dunia ini dan kembali kepada Bapa yang mengutus Dia. Yesus telah menyelesaikan pekerjaan-Nya di bumi (Yoh. 17:4). Mereka bahkan tidak bisa menangkap Yesus, apalagi membunuh Dia, sampai saat yang tepat tiba." ${ }^{45}$

Yesus adalah Anak Tunggal Bapa yang datang dalam rupa seorang manusia untuk menebus dosa melalui kematian-Nya di kayu salib dan semua ada di dalam kehendak Allah. Penekanan bahwa Yesus hidup dalam kehendak Bapa memungkinkan Dia mengetahui waktunya sudah dekat untuk kembali kepada Bapa. Visi itulah yang membuat kehidupan dan kepemimpinan Yesus berhasil. Kouzes dan Posner menuliskan dalam bukunya bahwa visi memiliki peran yang sangat penting dalam kepemimpinan:

"Visi berasal dari kata yang secara literal berarti "melihat". Tidak ada kata yang
lebih baik dibandingkan istilah visi untuk menjelaskan kemampuan melihat ke
depan (forward-looking) dan memahami potensi-potensi yang ada di masa depan
(foresightes)? Visi mengandung arti suatu orientasi masa depan. Sebuah visi
adalah sebuah gambaran tentang apa yang bisa terjadi. Metafora-metafora visual
adalah sesuatu yang lazim ketika kita membicarakan tujuan strategis dari sebuah
organisasi. Visi berkonotasi sebuah standar keunggulan, sebuah cita-cita. Visi
juga menyiratkan suatu pilihan nilai-nilai. Visi juga memiliki kualitas keunikan.
Visi menyiratkan hal-hal yang membuat sesuatu menjadi bersifat khusus."

Visi adalah harga mati untuk seorang pemimpin, karena keberhasilan dari kepemimpinan adalah pemimpin yang memiliki visi. Penulis memiliki pemahaman bahwa salah satu karakteristik dari kepemimpinan Yesus yaitu Dia sedang dan terus menerus mengetahui waktunya, karena pengetahuan Yesus adalah sempurna adanya. Dengan demikian keberhasilan kepemimpinan kristen adalah seorang pemimpin yang memiliki visi.

Kata "menanggalkan" berasal dari bahasa Yunani $\tau i ́ \theta \eta \sigma \iota \nu$ (tithesin) dari kata dasar $\tau i ́ \theta \eta \mu \iota$ (tithemi) yang memiliki arti meletakkan, membaringkan, menempatkan, menekuk, menghidangkan, menyerahkan, menanggalkan, menjelaskan, membuat, menetapkan, menentukan. ${ }^{47}$ NIV menggunakan kata took off artinya telah melepaskan atau menanggalkan, KJV memakai kata laid Inside artinya telah menyingkirkan ke samping atau ke sebelahnya. Kata $\tau i \dot{\theta}\rceil \iota \iota$ (tithesin) merupakan kata kerja present active indicative $3 r d$ person singular. ${ }^{48}$ Present active indikative berati perbuatan yang sedang dan terus menerus dilakukan. $3 r$ person singuler merupakan orang ketiga tunggal berarti dia. Jadi kata kerja present active indicative 3rd person singular dapat diartikan bahwa Dia (mengacu kepada pribadi Yesus), sedang menanggalkan dan terus-menerus menangalkan

\footnotetext{
${ }^{45}$ Warren W. Wiersbe, The Bible Exposition Commentary, (Wheaton: Victor Books, 2001), 344.

${ }^{46}$ James M. Kouzes dan Barry Z. Posner, The Leadership Challenge, (San Fransisco: Jossey-Bass, 1995), 95

${ }^{47}$ Hasan Sutanto Interlinier Perjanjian Baru Jilid II ..., 754

${ }^{48}$ Hasan Sutanto Interlinier Perjanjian Baru Jilid I ..., 569
} 
jubahnya. Hal ini dilatarbelakangi dari pengetahuan Yesus yang sempurna sebagai seorang guru dan pemimpin. Ia sungguh menyadari bahwa itu adalah waktu yang tepat untuk menunjukkan kepada para murid bagaimana sikap rendah hati yang harus dimiliki oleh para murid sehingga mereka dapat menjadi pemimpin yang berhasil. Hal ini diperkuat oleh pendapat Gaebelein bahwa sewaktu waktu selama Yesus sedang makan bersama dengan para murid, Dia melepaskan jubah-Nya, menjalin handuk atau serbet mengelilingi pinggangnya dan mulai tampil untuk bekerja sebagai pelayan yang tidak diperkenalkan. ${ }^{49}$ Senada dengan itu Lindars menjelaskan bahwa yang wajib untuk dilihat adalah simbol atau tanda dari meninggalkan kehidupannya. Yesus melucuti untuk tindakan yang sama seperti seorang budak. ${ }^{50}$ Dengan demikian, tindakan ketika Yesus menaggalkan jubah-Nya bukan hanya untuk menunjukkan sikap dari kerendahan hati-Nya saat itu saja tetapi kerendahan hati Yesus itu harus terus menerus diterapkan oleh murid-murid sebagai seorang yang akan menjadi pemimpin Kristen.

Kata "membasuh" berasal dari bahasa Yunani $\nu i \pi \tau \in \iota \nu$ (niptein) dari kata dasar $\nu i ́ \pi \tau \omega$ (nipto) yang memiliki arti membasuh. ${ }^{51} \mathrm{NIV}$ dan KJV menggunakan kata yang sama to wash artinya mencuci (lebih dari sekedar membasuh dan saat itu juga dilakukan). Kata vi $\pi \tau \in \iota$ (niptein) merupakan kata kerja present active infinitive. ${ }^{52}$ Present merupakan tindakan yang sedang dilakukan sedangkan active infinitive merupakan hal yang dilakukan dengan sebuah tujuan dan ada hasil dari tindakan yang dilakukan. Jadi kata kerja present active infinitive di sini dapat diartikan Yesus sedang mencuci (lebih dari sekedar membasuh) kaki para murid supaya mereka menjadi bersih. Harrison menjelaskan bahwa makna dari penyucian kaki tersebut bukan bersifat kuantitatif. Sebab tindakan itu melambangkan pembersihan batiniah. ${ }^{53}$ Lindars menambahkan tampaknya injil dalam bahasa ibrani berkata bahwa Yesus mencium kaki murid-murid sama dengan baiknya mencuci mereka. Berdasarkan analogi dalam Lukas 7:38. ${ }^{54}$ Injil itulah yang dimaksudkan untuk mencuci mereka dari dosa supaya mereka bersih. Sedangkan analogi dalam Lukas 7:38 yaitu seorang perempuan berdosa yang menerima pengampunan dari Yesus dan kemudian melayani-Nya dengan membasuh kaki Yesus lewat air matanya dan menyekanya menggunakan rambutnya. Carson menambahkan bahwa tindakan membasuh kaki yang dilakukan oleh Yesus merupakan simbol dari pembasuhan yang lengkap dari pelayananNya. Berdasarkan pemaparan di atas maka penulis menyimpulkan bahwa Yesus membasuh kaki murid-murid-Nya bukan dengan tanpa alasan, supaya para murid bersih. Membasuh kaki adalah gambaran dari krakteristik kepemimpinan Yesus yaitu melayani. Karakteristik kepemimpinan Yesus Kristus adalah pemimpin yang yang melayani.

\footnotetext{
${ }^{49}$ Frank E. Gaebelein, The Expositir's Bible Commentary..., 136

${ }^{50}$ Barnabas Lindars, The New Century Bible Commentary The Gospel Of John..., 450

${ }^{51}$ Hasan Sutanto, Jilid II..., 537

${ }^{52}$ Hasan Sutanto, Jilid I..., 569

${ }^{53}$ Everett F. Harrison, The Wycliffe Bible Commentary Volume 3, (Malang: Gandum Mas, 2008), 358

${ }^{54}$ Barnabas Lindars, The New Century Bible Commentary The Gospel Of John..., 450
} 
Kata "bersih" berasal dari bahasa Yunani $\kappa \alpha \theta \alpha \rho \circ \iota$ (kataroi) dari kata dasar $\kappa \alpha \theta \alpha \rho o ́ \varsigma$ (kataros) yang memiliki arti bersih, murni, jernih, halal, suci ${ }^{55}$ NIV menggunakan kata was clean artinya telah bersih menunjukkan telah dilakukan, sedangkan KJV menggunakan kata "clean” artinya bersih. Kata kaqaroi (kataroi) merupakan kata sifat masculine plural nominative no degree. ${ }^{56}$ Masculine plural menyatakan jamak berjenis kelamin laki-laki. Nominatif menyatakan subyek kalimat sedangkan no degree dapat diartikan tidak ada gelar. Jadi kata sifat masculine plural nominative no degree dapat diartikan bahwa Yesus membersihkan mereka. Hendricsen menulis dalam bukunya bahwa Yesus membuat kamu bersih; ini menandakan bahwa kamu adalah pengikut di dalam karya penebusan yang mana penghinaan atas diriku menjadi jasa untukmu. ${ }^{57}$ Harrison menambahkan bahwa bersih menandakan mereka sudah lahir baru. ${ }^{58}$ Sedangkan frasa "tidak semua kamu bersih" mengarah kepada Yudas, orang yang tidak dilahirkan baru. Berdasarkan pemaparan di atas, maka penulis menyimpulkan bahwa kata bersih menyatakan pribadi yang telah lahir baru.

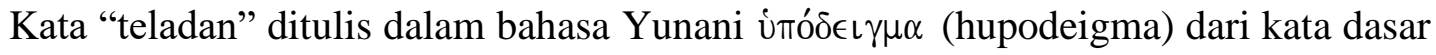

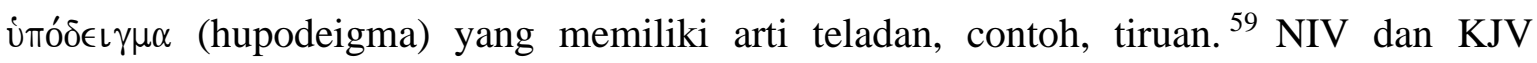
menggunakan kata yang sama an example artinya sebuah contoh atau teladan yang terus

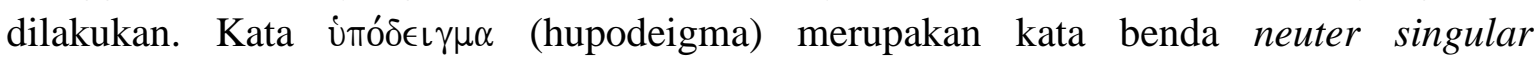
accusative. ${ }^{60}$ Neuter singguler menyatakan bentuk tunggal dan netral. Accusative merupakan objek penderita. Sehingga kata benda neuter singular accusative dapat diartikan memberikan teladan. Frasa "sebab aku telah memberikan teladan kepadamu" menyatakan bahwa Yesus menjadi objek langsung dari teladan itu sendiri. Hendricsen menemukakan bahwa contoh atau teladan itu bukan berarti sebagai bentuk pengabdian dari pembasuhan kaki yang biasa dilakukan di gereja. Yohanes menyebutnya sebagai contoh atau teladan, yang mana itu berarti menekankan pada sikap batin yang menghamba atau rendah hati dan sukarela atau tulus untuk melayani yang lain. ${ }^{61}$ hal ini diperjelas melalui perkataan Yesus kepada murid-murid: "apakah kamu tahu apa yang sudah aku lakukan pada kalian?" apakah kamu memahami pengajaran praktis yang positif yang mana Aku hanya berikan kepadamu? Dia tidak pernah memuaskan dengan hal-hal yang negatif. Ini berarti menegur, melindungi dengan kasih, memberikan kritik atau saran yang positif, lebih sering lebih baik dari menyatakan teguran. ${ }^{62}$ Setelah melakukan penggalian teks dan didukung oleh tafsiran-tafsiran, maka penulis menyimpulkan bahwa karakteristik kepemimpinan Yesus adalah menjadi teladan. Kepemimpinan yang berhasil adalah

\footnotetext{
${ }^{55}$ Hasan Sutanto, Interlinier Perjanjian Baru Jilid II ..., 409

${ }^{56}$ Hasan Sutanto, Interlinier Perjanjian Baru Jilid I..., 570

${ }^{57}$ William Hendriksen, New Testament Commentary John..., 233

${ }^{58}$ Everett F. Harrison, The Wycliffe Bible Commentary..., 358

${ }^{59}$ Hasan Sutanto, Interlinier Perjanjian Baru Jilid II..., 780

${ }^{60}$ Hasan Sutanto, Interlinier Perjanjian Baru Jilid I..., 571

${ }^{61}$ William Hendriksen, New Testament Commentary John..., 234

${ }^{62}$ William Hendriksen, New Testament Commentary John..., 234
} 
kepemimpinan yang seimbang. Tidak cukup dengan teori kepemimpinan yang baik tetapi juga harus diimbangi dengan pengajaran praktis.

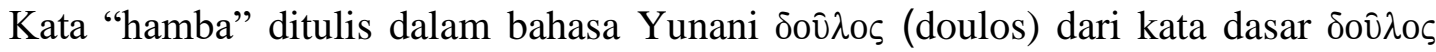
(doulos) yang memiliki arti hamba, pengawal raja, orang yang bergantung pada. ${ }^{63} \mathrm{NIV}$ dan

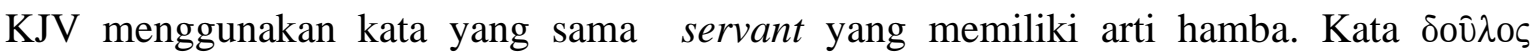
(doulos) merupakan kata benda masculine singuler nominative ${ }^{64}$ merupakan kata benda berjenis kelamin tunggal yang menjadi subyek kalimat. Jadi dapat diartikan seorang hamba. Menurut Douglas seorang hamba sama sekali tidak mempunyai hak dalam rumahnya. Sedangkan Guitrie memaparkan bahwa seorang utusan (yun apostolos) merupakan suatu peringatan bahwa posisi para rasul mengandung banyak tantangan besar, karena diwajibkan untuk bersesuaian dengan sikap Dia yang mengutus mereka, walaupun sekiranya ini akan membawa kepada kehinaan. ${ }^{65}$ Paulus menekankan kehambaan Yesus dalam Filipi 2:6-8. "Yang walaupun dalam rupa Allah, tidak menganggap kesetaraan dengan Allah itu sebagai milik yang harus dipertahankan, melainkan telah mengosongkan diri, dan mengambil rupa seorang hamba, dan menjadi sama dengan manusia. Dan dalam keadaan sebagai manusia, Ia telah merendahkan diri-Nya dan taat sampai mati, bahkan sampai mati di kayu salib." Seluruh kajian di atas menunjukkan bahwa hamba menggambarkan kerendahan hati dan ketaatan. Dimana seorang hamba harus menjalankan perintah tuannya tanpa ada bantahan terhadap tugas yang diberikan. Model hamba telah diberikan oleh Yesus yaitu melayani dan bukan dilayani, berkurban untuk orang lain dan bukan mencari keuntungan pribadi. Hamba adalah milik tuannya dan memiliki kewajiban untuk melaksanakan tugas sesuai keinginan tuannya. Kepemimpinan Kristen adalah kepemimpinan yang memiliki karakteristik yang unik, dimana seorang pemimpin harus taat terhadap perintah tuannya yaitu Sang pemimpin sejati karena Dia adalah kepala gereja.

\section{Metode Penelitian}

Penelitian ini menggunakan metode penelitian deskriptif melalui survei literatur dan lapangan. Metode deskriptif yaitu mengumpulkan data untuk memberikan gambaran atau penegasan tehadap suatu konsep atau gejala serta menjawab pertanyaan berkenaan dengan kasus yang berbeda. Tujuan penelitian deskriptif adalah untuk membuat deskripsi gambaran atau lukisan secara sistematis, faktual, dan akurat mengenai fakta-fakta, sifatsifat serta fenomena yang diselidiki. Berdasarkan hasil analisis literatur dan penelitian lapangan, penulis menyimpulkan bahwa: Pertama, dasar model kepemimpinan Kristen Yesus Kristus adalah kasih yang sempurna dan tanpa batas, tidak tebang pilih dalam pelayanan. Kedua, karaktersistik model kepemimpinan Yesus Kristus adalah: Kepemimpinan yang visioner; Rendah hati; Melayani; Menjadi teladan; dan Kepemimpinan sebagai hamba. Hal ini masih relevan bagi para pemimpin Gereja masa kini, meskipun dari hasil penelitian masih banyak yang belum memahami dan belum

\footnotetext{
${ }^{63}$ Hasan Sutanto, Interlinier Perjanjian Baru Jilid II..., 224

${ }^{64}$ Hasan Sutanto, Interlinier Perjanjian Baru Jilid I..., 571

${ }^{65}$ D. Guitrie, Tafsiran Alkitab Masa Kini, (Jakarta: BPK Gunung Mulia, 1981), 325
} 
SHAMAYIM: Jurnal Teologi Dan Pendidikan Kristiani, Vol 1, No 1, 2020

mampu melaksanakan implementasi kepemimpinan Yesus Kristus dalam kepemimpinannya pada masa kini.

\section{Pembahasan dan Hasil}

Berdasarkan hasil penelitian lapangan terhadap pemahaman dan implementasi kepemimpin Yesus Kristus dari pemimpin Kristen masa kini melalui sebaran angket dan wawancara, diperoleh hasil penelitian sebagai berikut: semua informan pernah mengetahui istilah kepemimpinan; sebagian besar informan mengetahui istilah kepemimpinan dari khotbah; sebagian besar informan memahami kepemimpinan adalah seni/gaya dalam memimpin; sebagian besar informan memahami istilah kepemimpinan dari kata pemimpin; sebagian besar informan memahami tujuan kepemimpinan supaya mampu memimpin orang yang dipimpinnya, supaya mampu mengarahkan orang yang dipimpinnya dan supaya mampu mencapai tujuan yang ingain dicapai; sebagian besar informan memahami memahami orientasi kepemimpinan adalah fungsi; sebagian besar informan pernah membaca kepemimpinan Yesus Kristus di dalam Alkitab; sebagian besar informan memahami kepemimpinan Yesus Kristus terdapat dalam Yohanes 13:1-20; semua informan pernah membaca Yohanes 13:1-20; semua informan lebih dari lima kali membaca Yohanes 13:1-20; semua informan memahami hal penting dalam Yohanes 13:120 tentang kepemimpinan, kasih dan teladan; semua informan memiliki pemahaman tentang kepemimpinan adalah melayani, mengasihi dan menjadi teladan; semua informan memahami dasar kepemimpinan Yesus Kristus adalah kasih; semua informan memahami bahwa dasar kepemimipinan Kristen adalah kasih Allah dan oleh mengasihi Allah; semua informan menerapkan kasih Allah dalam kepemimpinan servant leadership; sebagian besar informan informan memahami dampak dari mengasihi Allah yaitu menjadi berkat; sebagian besar informan memahami faktor yang mempengaruhi kepemimpinan Yesus Kristus dalam Yohanes 13:1-20 adalah kepemimpinan Yesus Kristus memiliki dasar dan karakteristik; sebagian besar informan memahami karakteristik kepemimpinan Yesus Kristus dalam Yohanes 13:1-20 adalah melayani, teladan dan visioner; sebagian besar informan memiliki pemahaman tentang visi adalah melihat kedepan, tujuan yang ingin dicapai dan gambaran; sebagian besar informan memahami visi adalah hal yang sangat penting bagi bagi gereja; sebagian besar informan sangat setuju Yesus Kristus adalah pemimpin yang visioner; sebagian besar informan memahami kepemimpinan visioner Yesus Kristus masih relevan; semua informan sangat yakin bahwa rendah hati adalah karakteristik kepemimpinan Yesus Kristus; semua informan memahami bahwa menjadi bos bukanlah karakteristik kepemimpinan Yesus Kristus menurut Yohanes 13:1-20; semua informan setuju pemimpin adalah pelayan; sebagian besar informan memahami pemimpin Kristen harus menjadi teladan terkait integritas; sebagian besar informan alasan pemimpin Kristen adalah seorang hamba karena Yesus Kristus meneladankan demikian; sebagian besar informan memahami relevansi kepemimpinan Yesus Kristus sedang diterapkan; sebagian besar informan memahami dampak kepemimpinan majelis Kristen Masa Kini membuat jemaat termotivasi untuk menjadi terang bagi lingkungan sekitar; dan semua 
informan memahami model kepemimpinan Yesus Kristus masih relevan untuk sekarang dan seterusnya bagi pemimpin Kristen Masa Kini.

Berdasarkan hasil penelitian terhadap pemahaman dua puluh empat pemimpin Kristen melalui angket dan wawancara di atas, peneliti menemukan adanya kelebihan, namun masih banyak kekurangan pemimpin Kristen dalam implementasi model kepemimpinan Yesus Kristus, oleh sebab itu peneliti menawarkan temuan model kepemimpinan Yesus Kristus bagi pemimpin Kristen masa kini

\section{Kesimpulan}

Kepemimpinan adalah bagian yang integral dalam sepanjang peradaban manusia karena semua orang membutuhkan pemimpin dan semua orang bisa menjadi seorang pemimpin, minimal mereka akan memimpin diri mereka sendiri. Kepemimpinan adalah pengaruh. Dimana tujuan dari dipilihnya seorang pemimpin adalah untuk mempengaruhi, menegur, mengarahkan supaya orang-orang yang dipimpinnya sampai kepada tujuan yang ingin dicapai. Dengan demikian kepemimpinan lebih cenderung kepada fungsi dan bukan posisi. Dunia menawarkan dan membentuk para pemimpin yang lebih berfokus kepada posisi dan otoritas. Tak ayal jika banyak pemimpin Kristen sekalipun terpengaruh untuk lebih mengutamakan kepentingan pribadi dan mengesampingkan kepentingan kelompok itu sendiri. Bahkan beberapa dari mereka menghalalkan segala cara untuk untuk mencapi maksud dan tujuannya.

Rasul Yohanes dalam Yohanes 13:1-20 dengan jelas menuliskan Kepemimpinan Yesus Kristus supaya para pemimpin Kristen memiliki teladan yang hidup yang bisa mereka hidupi di dalam kepemiminannya. Adapun beberapa hal yang menjadi pondasi dari kepemimpinan Yesus, yaitu: pertama, dasar dari kepemimpinan Yesus Kristus adalah kasih yang utuh dan tanpa batas. Kedua, karaktersitik dari kepemimpinan Yesus Kristus adalah: Pertama, visioner, hal ini dikarenakan visi memegang peranan penting dalam kehidupan kepemimpinan, dimana visi yang mengarahkan pandangan para pemimpin gereja untuk melihat, memprediksi dan menentukan kemana arah gereja kedepannya. Kedua, rendah hati, tidak menganggap diri lebih dari dari pada orang lain. Ketiga, melayani, tanpa pemahaman yang benar setiap pemimpin Kristen hanya akan menjalankan pelayanan sebagai pekerjaan atau rutinitas belaka. Keempat, teladan, memberikan seluruh hidup untuk menjadi teladan, karena satu teladan lebih baik dari pada seribu nasihat. Kelima, sebagai hamba, menyadari bahwa status sebagai seorang hamba Tuhan membawa para pemimpin sampai kepada satu pengertian bahwa semua hanya oleh anugerah-Nya.

\section{Daftar Pustaka}

Abieno, J. L. CH.,

n.d Yesus Sang Mesias Dan Sang Anak. Jakarta: BPK Gunung Mulia

Alwi, Hasan,

2005 Kamus Besar Bahasa Indonesia. Jakarta: Balai Pustaka

Beasley-Murray, George R., 
SHAMAYIM: Jurnal Teologi Dan Pendidikan Kristiani, Vol 1, No 1, 2020

1987 Word Blibical Commentary Johnvol 36. Waco, Texas: Word Books Publisher

Benyamin, Samuel,

2010 Perjanjian Baru. Bandung: Bina Media Informasi

Blanchard, Klen, \& Phil Hodges,

2007 Lead Like Jesus. Tanggerang: Visimedia

Brill, J. Wesley,

1976 Tafsiran Injil Yohanes. Bandung Kalam Hidup

Browning, W.R.F.,

2015 Kamus Alkitab. Jakarta: BPK Gunung Mulia

Carson, D. A., \& Douglas J. Moo,

2016 Introduction to the New Testament. Malang: Gandum Mas

Darmaputra, Eka,

2005 Kepemimpinan Dalam Perspektif Alkitab. Yogyakarta: Kairos

Books

Douglas, J.D.,

1992 Ensiklopedi Alkitab Masa Kini Jilid 1. Jakarta: Yayasan Komunikasi

Bina Kasih

Enns, Paul,

2004 The Moody Handbook of Theology. Malang: Literatur SAAT

Fee, Goordon D. dan Douglas Stuard,

2009 Hermeneutik. Malang: Gandum Mas

Gaebelein, Frank E.,

The Expositir's Bible Commentary. USA: New York International

Bible Society

Gartenhaus, Jacob,

1970 The Jewis Conception Of The Messiah. Christianity Today

Gutrie, Donald,

2012 Pengantar Perjanjian Baru Vol 1. Surabaya: Momentum

1981 Tafsiran Alkitab Masa Kini. Jakarta: BPK Gunung Mulia

Goodlell, Gary,

2012 Cara Yesus Memimpin. Yogyakarta: ANDI

Hagelbreg, Dave,

1999 Tafsiran Injil Yohanes (Pasal 1-5) Dari Bahasa Yunani.

Yogyakarta: Yayasan Andi

Hamdi, Asep Saepul,

2014 Metode Penelitian Kuantitatif Aplikasi Dalam Pendidikan.

Yogyakarta: Deepublish

Harrison, Everett F.,

2008 The Wycliffe Bible Commentary Volume 3. Malang: Gandum Mas

Hayes, John H. \& Carl R. Holladay,

Copyright@ 2020, SHAMAYIM: Jurnal Teologi Dan Pendidikan Kristiani | 74 
Hotman P. Simanjuntak: Implementasi Kepemimpinan Yesus Kristus Menurut Yohanes 13:1-20

2006 Pedoman Penafsiran Alkitab. Jakarta: BPK Gunung Mulia

Hendriksen, William,

New Testament Commentary John. USA: Billing and Sons Limited

Henry, Metthew,

1983 The Bethany Commentary on the New Testament. Minneapolis:

Bethany House Pulisher

Holdcroft, L. Thomas,

1992 Kitab-Kitab Sejarah. Malang: Gandum Mas

Ismail, Andar,

2009 Selamat Melayani Tuhan. Jakarta: BPK Gunung Mulia

Jensen, Irving L.,

1970 Yohanes. Bandung: Kalam Hidup

Keating, Charles J.,

1987 Kepemimpinan Teori Dan Perkembangannya. Yokyakarta: Knisius

Kalusner, Joseph,

1995 The Messianic Idea In Israel. New York: MacMillan

Kouzes, James M. \& Barry Z. Posner,

1995 The Leadership Challenge. San Fransisco: Jossey-Bass

Lindars, Barnabas,

1952 The New Century Bible Commentary The Gospel of John. USA:

Division of Christian Education

Lumintang, Stevri Indra,

2015 Theologia Kepemimpinan Kristen. Jakarta: Geneva Insani Indonesia

MacDowell, Josh,

1997 Benarkah Yesus Itu Allah, Jakarta: BPK Gunung Mulia

Mangunhardjana, A.M.,

1986 Kepemimpinan. Yogyakarta: KANISIUS

Marxsen, Wili,

2005 Pengantar Perjanjian Baru: Pendekatan Kritis terhadap Masalah-

Masalahnya. Jakarta: BPK Gunung Mulia

Melton, M E.,

2003 Kamus Istilah Teologi Inggris-Indonesia. Malang: Gandum Mas

Monroe, Myles,

1991 The Spirit of Leadership. Jakarta Imanuel CBA

Morris, Leon,

2014 Teologi Perjanjian Baru. Malang: Gandum Mas

Mounce, William D.,

2015 Basics of Biblical Greek. Michigan: Zondervan Publishing House

Newman JR, Barclay M.,

2012 Kamus Yunani-Indonesia Untuk Perjanjian Baru. Jakarta: BPK

Copyright@ 2020, SHAMAYIM: Jurnal Teologi Dan Pendidikan Kristiani | 75 
Northouse, Peter G.,

Gunung Mulia

2013 Kepemimpinan: Teori dan Praktik. Jakarta: PT Indeks

Octavianus, Petrus,

2004 Alih Generasi Dan Kepemimpinan Dalam Garis Firman Allah.

Batu: Literatur YPPII

1988 Manajemen Dan Kepemimpinan Menurut Wahyu Allah. Malang:

Gandum Mas

Pentecost, J. Dwight,

1981 The Words and Works of Jesus Christ: A Study of The Life of

Christ. Grand Rapids Michigan: Zondervan

Peordarmita, W. C. S.,

2005 Kamus Besar Bahasa Indonesia. Jakarta: Balai Pustaka

Piper, John,

2008 Kesukaan Allah. Surabaya: Momentum

Posner, Kouzes,

2004 Tantangan Kepemimpinan: edisi ketiga. Jakarta: Penerbit

Erlangga

Rush, Myron,

1991 Pemimpin Baru. Jakarta: Yayasan Pekabaran Injil Imanuel

1987 The New Leader a Revolutionary Approach to Effective

Leadership. Wheaton: Victor Books

Sanders, J. Osland,

1979 Kepemimpinan Rohani. Bandung: Kalam Hidup

Sendjaya,

2004 Kepemimpinan Kristen. Yogyakarta: Kairos Books

Sudomo,

2009 Ciri Kepemimpinan Sejati. Yogyakarta: Andi

Supermoko, M.,

1999 Metode Pnenlitian Praktis. Yokyakarta: BPFE

Surakhmad, Winarno

1880 Pengantar Penelitian Ilmiah. Bandung: TARITO

Susanto, Agus,

2011 Tata Bahasa Yunani Koine. Semarang: Bina Media Informasi

Sutanto, Hasan,

1991 Hermeneutik: Prinsip Dan Metode Penafsiran Alkitab. Malang:

Literatur SAAT

2014 Perjanjian Baru Interlinier Yunani-Indonesia Jilid I \& II. Jakarta: LAI

Tenney, Merril C.,

1989 John: The Gospel of Belief. Michigan: Grand Rapids

ulluan, Ola,

Copyright@ 2020, SHAMAYIM: Jurnal Teologi Dan Pendidikan Kristiani | 76 
Hotman P. Simanjuntak: Implementasi Kepemimpinan Yesus Kristus Menurut Yohanes 13:1-20

1999 Introduksi Perjanjian Baru. Malang: Literatur YPPII

1993 Tafsiran Injil Yohanes 1-5. Batu: Sekolah Tinggi Teologia I-3

Wenham, J.W.,

1987 Bahasa Yunani Koine. Malang: SAAT

Wiersbe, Warren W.,

2001 The Bible Exposition Commentary. Wheaton: Victor Books

Wofford, Jerry C.,

2001 Kepemimpinan Kristen Yang Mengubahkan. Yogyakarta: ANDI

Wongso, Peter,

1998 Hikayat Yesus. Malang: Seminari Alkitab Asia Tenggara

Yarbrrough, Robert W.,

1991 Everyman's Bible Commentary: John. Chicago: Moody Press

\section{Sumber Dari Website:}

BibleWorks 7, LCC, c-/Program Files/ BibleWorks 7/inti/bw700.swc.

"Hamba Tuhan Bermasalah", www.KristenSkeptis.com diakses pada tanggal 27 november 2018 pukul 10.27 WIB.

http://www.lds.org/scriptures/gs/jesus-christ?lang=ind diakses pada tanggal 27 November 2018 pukul 11.00 WIB.. (font 12) 